УДК 616.348+616.351] - 006.6-089.168.06-002.4

DOI 10.11603/2414-4533.2018.1.8862

Сю. В. ДУМАНСЬКИЙ, С. П. ВОЛОШИН

Міський міжрайонний онкологічний диспансер, м. Маріуполь

\title{
Безпосередні результати лікування некрозу низведеної кишки після сфінктерозберігаючих операцій у хворих на рак прямої кишки
}

\begin{abstract}
Мета роботи: підвищення ефективності лікування хворих на рак прямої кишки.
Матеріали та методи. Матеріалом для роботи слугували дані 271 пацієнта з некрозом низведеної кишки. Усіх хворих з даним ускладненням розділили на дві групи: контрольну (176 пацієнтів) та досліджувану (95 пацієнтів).

Результати досліджень та їх обговорення. Для лікування хворих контрольної групи застосовували колостомію, для лікування пацієнтів досліджуваної групи - оптимізовано тактику лікування некрозу низведеної кишки залежно від часу її виникнення і рівня некрозу: у пацієнтів з раннім високим некрозом низведеної кишки показана ампутація низведеної кишки, у пацієнтів з раннім низьким некрозом низведеної кишки показане донизведення низведеної кишки зі сторони промежини; у пацієнтів з пізнім некрозом низведеної кишки показане відключення лівої половини товстої кишки шляхом формування петельної трансверзостоми на правій половині товстої кишки з одночасним тампонуванням тазової порожнини та армуванням анального каналу для запобігання його стенозу.

Інтраопераційні ускладнення спостерігали у $(10,3 \pm 1,8)$ \%, в контрольній групі - у $(13,1 \pm 2,5)$ \%. Застосування розробленої тактики дозволило знизити (р<0,05) ризик післяопераційних ускладнень у цієї категорії пацієнтів, ВР=0,54 (95 \% ДІ 0,29-0,99) порівняно з раніше використовуваною методикою. Частота післяопераційних ускладнень склала $(21,6 \pm 3,1)$ \% в контрольній

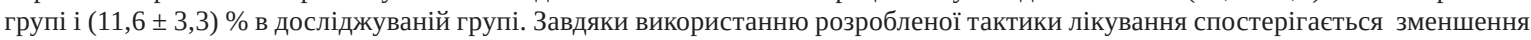
післяопераційної летальності у 2 рази - з (12,5 \pm 2,5) \% (22 пацієнти) до $(6,2 \pm 2,5)$ \% (6 пацієнтів).
\end{abstract}

Ключові слова: некроз низведеної кишки; колостомія; сфінктерозберігаючі операції; післяопераційна летальність.

Постановка проблеми і аналіз останніх досліджень та їх публікацій. Рак прямої кишки (ПК) посідає одне з провідних місць у структурі онкологічних захворювань у багатьох країнах світу [1, 2]. Так, у Великобританії у 2014 р. було зареєстровано 41265 випадків колоректального раку, який складає $11 \%$ від усіх злоякісних пухлин із першим у житті встановленим діагнозом [2]. В Україні спостерігається невелике зменшення захворювань на рак даної локалізації серед чоловіків і жінок протягом останніх 10 років. Якщо у 2006 р. цей показник складав 19,6, в тому числі 22,4 для чоловіків, 17,2 для жінок [3], то у 2016 році він складав 18,8; 21,5 і 16,4 відповідно [1]. На сьогодні хірургічний метод $є$ основним для лікування хворих на рак ПК $[4,5]$. Одним з найбільш поширених видів хірургічного втручання при раку ПК є передня резекція із виконанням тотальної мезоректумектомії $\mathrm{i}$, якщо це можливо, відновленням кишкової безперервності [5]. Існують два основні способи відновлення кишкової безперервності при виконанні резекції ПК - це формування колоректального анастомозу (апаратного або вручну) та низведення ободової кишки в промежину з утворенням колоанального анастомозу. 3 функціональної точки зору найбільш виграшним є формування колоректального анастомозу із застосуванням апаратного шва. Негативні пункти цього варіанту включають високу вартість зшивальних апаратів, необхідність формування протективної стоми, неможли- вість формування апаратного анастомозу за наявності запальних змін кишкової стінки тощо. Тому в деяких випадках хірург змушений з метою встановлення кишкової безперервності користуватися способом низведення ободової кишки на промежину. Одним з найбільш грізних ускладнень резекції прямої кишки із застосуванням методу низведення ободової кишки на промежину є некроз низведеної кишки (ННК). Незважаючи на велику кількість публікацій, присвячених даному ускладненню, питання щодо профілактики та лікування проблеми НHК досі залишаються невирішеними.

Мета роботи - підвищення ефективності лікування хворих на рак прямої кишки.

Матеріали і методи. Матеріалом для роботи слугували дані 271 пацієнта з ННК, які проходили лікування в період з 1990 до 2014 р.: 126 жінок (47 \%) та 145 чоловіків (53 \%). Прооперовано $161((59,4 \pm 3,0) \%)$ пацієнта, віком 60 років. Усіх хворих з ННК розділили на дві групи: контрольну, у якій використовували стандартні схеми лікування ННК, та досліджувану, у якій застосовували розроблений комплекс медичних заходів. До контрольної групи увійшли 176 пацієнтів, яких прооперували в період з 1990 до 1999 р., до досліджуваної групи увійшли 95 пацієнтів, яких прооперували в період з 2000 до 2014 р.

Статистичні дані оброблені методом біостатистики [6]. При оцінці ефективності методів лі- 
кування розраховували показник відносного ризику (ВР). Для узагальнення отриманих результатів на генеральну сукупність розраховувався також 95 \% довірчий інтервал (95% ДІ) для ВР.

Результати досліджень та їх обговорення. Пухлина локалізувалась у проксимальних відділах прямої кишки у 121 ((44,7 $\pm 3,0)$ \%) пацієнта, у

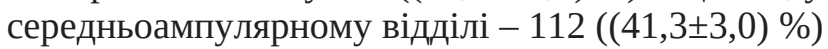
пацієнтів, рідше в нижньоампулярному відділі ПК. Аденокарцинома спостерігалась у 229 (84,5 \%) пацієнтів, інші морфологічні форми - у 15,5 \%. Більшість пацієнтів прооперували за наявності локально-поширеного пухлинного процесу (Т4) - 241 (88,9 \%) спостережень. Метастатичні ураження регіонарних лімфатичних вузлів різних рівнів спостерігались у 99 (36,5 \%) пацієнтів. Віддалені метастази спостерігалися у 34 (12,5 \%) пацієнтів, найбільш поширеною локалізацією віддалених метастазів була печінка. У 144 хворих (53,1 \%) поширеність пухлинного процесу відповідала T4N0M0. У 73 (26,9 \%) пацієнтів спостерігали 86 різних ускладнень пухлинного процесу; частіше спостерігалася кишкова непрохідність різного ступеня - у 63 (73,3 \%) пацієнтів. Супутні захворювання спостерігали у 62,4 \% хворих; частіше зустрічалися захворювання серцево-судинної і дихальної систем.

Змішана форма росту пухлини спостерігалась у 184 (67,9 \%) пацієнтів, рідше зустрічалися ендофітна та екзофітні форми - 65 (24,0%) і 22 (8,1%) відповідно.

При лікуванні хворих на рак ПК ми використовували три види хірургічних втручань з низведенням ободової кишки на промежину - це проксимальна резекція ПК 3 низведенням (ПРН), черевно-наданальна резекція ПК (ЧНР) та черевно-анальна резекція ПК (ЧАР). У всіх випадках, рівень перев'язування судин не змінився - нижню брижову артерію і вену перев’язували у місці нижче відходження лівої ободової артерії. При ПРН виконували часткову мезоректумектомію (ЧМЕ), при ЧНР та ЧАР - тотальну мезоректумектомію (ТМЕ). При ПРН ободову кишку на промежину низводили позаду кукси прямої кишки через підслизовий тунель між відсепарованою слизовою оболонкою анального каналу і заднім напівколом зовнішнього сфінктера. При ЧНР ободову кишку на промежину низводили через евагіновану та демускуляризовану куксу прямої кишки. При ЧАР ободову кишку на промежину низводили через демукозований анальний канал.

Найчастіше некроз низведеної кишки спостерігали у пацієнтів після ЧАР - 223 (82,3 \%) ви- падки, рідше після ЧНР і ПРН - 28 (10,3 \%) та 20 (7,4 \%) відповідно.

3271 пацієнта, 146 (53,9 \%) у передопераційний період отримали хіміо-променеву терапію у різних поєднаннях. У контрольній та досліджуваній групах цей показник склав 54,6 \% і 52,6 \% відповідно. Частіше пацієнти у неоад’ювантному режимі отримували інтенсивний курс променевої терапії - 82 (56,2 \%) пацієнти.

У результаті проведеного аналізу не спостерігали істотних відмінностей стану пацієнтів у досліджуваній та контрольній групах (р > 0,05 за всіма параметрами). Це дозволяє нам порівнювати результати лікування і адекватно оцінювати їх переваги і недоліки.

При лікуванні хворих ННК використовували тактику лікування, основану на трьох базових параметрах: термін розвитку некрозу, його висота і стан хворого, зокрема, наявність або відсутність перитоніту. У своїй роботі усі випадки некрозу низведеної кишки ми розділили за рівнем його протяжності на “низький” (розташований в анальному каналі або над ним до 3 см) i “високий” (більше 3 см), а за часом його виникнення - на “ранній” (до 3 діб) та пізній (більше 3 діб).

У пацієнтів з “раннім високим” ННК незалежно від типу радикального операційного втручання (ЧАР, ЧНР або ПРН) застосовували ампутацію низведеної кишки. Для цього виконували релапаротомію, ревізію черевної порожнини, діставали у рану з малого тазу низведену кишку, визначали рівень життєздатної кишки, на цьому місці кишку резеціювали, видаляли некротизовану ділянку, а життєздатний проксимальний відрізок кишки виводили до черевної стінки у лівій здухвинній ділянці у вигляді однодульної плоскої колостоми. При цьому кишку проводили підчеревинно, малий таз промивали із застосуванням 1600-2000 мл 0,9 \% розчину хлориду натрію, а потім ретельно відновлювали очеревину малого таза. За відсутності ознак розлитого перитоніту рану черевної стінки ушивали до двох дренажів, введених у малий таз, за наявності перитоніту - санували черевну порожнину та дренували ії з чотирьох точок - у здухвинних ділянках із двох сторін. Протягом післяопераційного періоду виконували щоденні промивання малого таза як через анус, так і через дренаж, встановлений на сідниці.

У пацієнтів 3 “раннім низьким” ННК застосовували донизведення низведеної кишки з боку промежини. Для цього, при розвитку ННК після ЧАР і ПНР під внутрішньовенним наркозом видаляли шви, які фіксують низведену кишку до шкіри періанальної ділянки, виконували пальцеву ре- 
візію анального каналу, при цьому розриваючи м'які зрощення між нею і анальним каналом, дістали трансплантат товстої кишки до життєздатного рівня, прошивали кишку на життєздатному рівні за допомогою апарата УО-60 і видаляли некротизовану ділянку. Після цього трансплантат товстої кишки зачіплювали двома довгими клемами Аліса і розташовували її до порожнини малого тазу. Виконували резекцію і санацію анального каналу та малого таза через анальний канал - видаляли некротичні тканини, промивали порожнину малого таза із застосуванням 400-800 мл 0,9\% розчину хлориду натрію, після чого дренували малий таз за допомогою додаткового дренажу на другій сідниці. За допомогою клем Аліса діставали життєздатний трансплантат товстої кишки до життєздатного рівня і фіксували його при наявності надлишку 10-20 мм до шкіри періанальної ділянки. Після ЧНР цю операцію доповнили демукозацією анального каналу і видаленням кукси прямої кишки.

У хворих з “пізнім низьким” ННК, незалежно від типу радикального операційного втручання (ЧАР, ЧНР або ПРН), донизведення трансплантату товстої кишки (ТK) не представляється можливим. У таких пацієнтів показане відключення лівої половини ТК шляхом формування петельної трансверзостоми на правій половині ТК з одночасним тампонуванням порожнини таза та армуванням анального каналу для запобігання його стенозу. У цьому випадку ми зазвичай використовуємо трубки медичні гумові, проводячи її через губку, форму якої моделюємо залежно від форми порожнини в ділянці малого таза. У випадку великої порожнини в ділянці малого таза, через губку поблизу армованої трубки, вводимо тонку трубку від системи для внутрішньовенних інфузій, проксимальний кінець якої проводимо до порожнини, а дистальний виводимо назовні. Трубка медична гумова, перебуваючи в порожнині малого таза, виключає розвиток його стенозу, а тонка трубка використовується для зрошення порожнини малого таза із застосуванням розчину антисептиків (хлоргексидин, декасан, тощо). “Пізнього високого” некрозу у наших пацієнтів не спостерігали.

Консервативне лікування ННК застосовували до пацієнтів з “пізнім низьким” ННК, у яких частина стіни низведеної кишки, яка розташовується в анальному каналі, залишалась життєздатною і не спостерігалося ознак запального процесу в області малого таза. Консервативне лікування полягало в очисних клізмах і введенні до анального каналу репаративних мазей (наприклад, метилурацилової).

Інформація про методи лікування ННК (табл. 1): консервативне лікування застосовували у 76 (28,0 \%) пацієнтів, хірургічне у 195 (72,0 \%).

Найбільш поширеним хірургічним втручанням була колостомія - у 101 ((51,8土3,6) \%) пацієнта. Друге місце посідає донизведення трансплантату - 58 ((29,7 $\pm 3,2) \%)$ спостережень. Ампутація

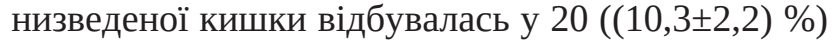

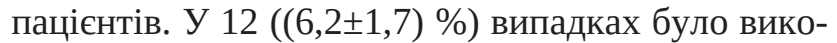
нано донизведення мобілізованої кишки з коло-

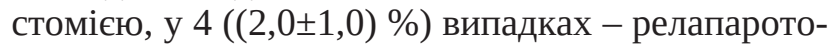
мія з ренизведенням.

Використання розробленої тактики лікування дозволило знизити частоту виконання колостоми, ВР (відносний ризик) = 0,6 (95 \% ДІ (довірчий інтервал) 0,4 - 0,9) порівняно з контрольною групою.

У результаті такого комплексного підходу ми змогли знизити частоту ННК у хворих на КРP.

При виконанні хірургічного втручання у пацієнтів, у яких згодом розвинувся ННК, інтраопераційні ускладнення спостерігали у 28 ((10,3 \pm 1,8) \%) з 271 хворих. В контрольній групі інтраопераційні ускладнення спостерігали у 23 ((13,1 \pm 2,5) \%) з 176 пацієнтів, у досліджуваній - у 5 паці-

Таблиця 1. Методи лікування некрозу низведеної кишки у хворих досліджуваної групи

\begin{tabular}{|c|c|c|c|c|c|c|}
\hline \multirow{2}{*}{$\begin{array}{c}\text { Методи лікування некрозу } \\
\text { низведеної кишки }\end{array}$} & \multicolumn{2}{|c|}{$\begin{array}{c}\text { Контрольна група } \\
(\mathrm{n}=176)\end{array}$} & \multicolumn{2}{|c|}{$\begin{array}{c}\text { Досліджувана група } \\
(\mathrm{n}=95)\end{array}$} & \multicolumn{2}{|c|}{$\begin{array}{c}\text { Всього } \\
(n=271)\end{array}$} \\
\hline & абс. & $\% \pm m \%$ & абс. & $\% \pm m \%$ & абс. & $\% \pm m \%$ \\
\hline Консервативне лікування & 43 & $24,4 \pm 3,2$ & 33 & $34,7 \pm 4,9$ & 76 & $28,0 \pm 2,7$ \\
\hline Хірургічне лікування & 133 & $75,6 \pm 3,2$ & 62 & $65,3 \pm 4,9$ & 195 & $72,0 \pm 2,7$ \\
\hline \multicolumn{7}{|l|}{ в тому числі: } \\
\hline колостомія & 76 & $57,1 \pm 4,3$ & 25 & $40,3 \pm 6,2$ & 101 & $51,8 \pm 3,6$ \\
\hline донизведення трансплантату & 37 & $27,8 \pm 3,9$ & 21 & $33,9 \pm 6,0$ & 58 & $29,7 \pm 3,2$ \\
\hline ампутація низведеної кишки & 15 & $11,3 \pm 2,7$ & 5 & $8,1 \pm 3,5$ & 20 & $10,3 \pm 2,2$ \\
\hline донизведення \pm колостома & 5 & $3,8 \pm 1,7$ & 7 & $11,3 \pm 4,0$ & 12 & $6,2 \pm 1,7$ \\
\hline релапаротомія土 ренизведення & - & - & 4 & $6,4 \pm 3,1$ & 4 & $2,0 \pm 1,0$ \\
\hline Всього & 176 & 100,0 & 95 & 100,0 & 271 & 100,0 \\
\hline
\end{tabular}


єнтів ((5,3 $\pm 2,3) \%)$, різниця не має статистичної значущості, p = 0,06 (точний критерій Фішера). Найбільш поширеним інтраопераційним ускладненням була перфорація пухлини, яка спостерігалася у 20 пацієнтів, що склало $(71,4 \pm 8,5)$ \% у структурі інтраопераційних ускладнень і (7,4 \pm 1,6) \% від числа прооперованих.

У 271 пацієнта з ННК частота післяопераційних ускладнень склала $(18,1 \pm 2,3)$ \% (49 пацієнтів). Застосування розробленої тактики дозволило знизити частоту післяопераційних ускладнень 3 $(21,6 \pm 3,1) \%$ (38 пацієнтів) в контрольній групі до $(11,6 \pm 3,3)$ \% (11 пацієнтів) у досліджуваній групі (p = 0,047, точний критерій Фішера). Застосування розробленої тактики дозволило знизити ризик післяопераційних ускладнень, ОР = 0,54 (95\% ДІ 0,29-0,99) порівняно з контрольною групою. У структурі післяопераційних ускладнень превалювали гнійно-септичні (абсцес малого таза, перитоніт, орхоепідидиміт, ректо-вагінальний свищ, цистит, флегмона передньої черевної стінки) - 53 ((71,6 \pm 5,2) \%) спостереження. Частка ускладнень, пов’ язаних із порушенням системи РАСК (гострий інфаркт міокарда, пневмонія, гостра печінковониркова недостатність, тромбоемболія легеневої артерії, тромбоз мезентеріальних судин, ДВС синдром, крововиливи у надниркові залози) склала 17 ((23,0 \pm 4,9) \%) випадків. Не встановлено вірогідної відмінності досліджуваної та контрольної груп щодо частоти гнійно-септичних ускладнень (p = $0,177)$ і ускладнень, пов'язаних із порушенням у системі PACK (p = 0,180).

3271 пацієнта з ННК після операції помер-

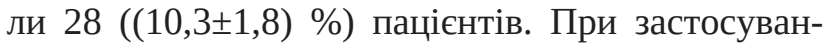
ні розробленої тактики лікування післяопераційна летальність склала (6,2 $\pm 2,5)$ \% (6 пацієнтів), в контрольній групі (12,5 \pm 2,5) \% (22 пацієнти), різниця не має статистичної значущості ( $=0,17$ за критерієм хі-квадрат). Найбільш поширеною причиною смертельних випадків був абсцес малого таза $(32,1 \pm 8,8) \%$. Вірогідної різниці частоти абсцесу як причини смерті в досліджуваній та контрольній групах не спостерігали (p = 0,184).

\section{СПИСОК ЛІТЕРАТУРИ}

1. Рак в Україні в 2015-2016 р. (захворюваність, смертність, показники діяльності онкологічної служби) / Бюлетень національного канцер-реєстру України. - К., 2017. - № 18. - 126 с. 2. http://www.cancerresearchuk.org/health-professional/cancerstatistics/statistics-by-cancer-type/bowel-cancer/incidence.

3. Рак в Україні в 2006-2007 р. (захворюваність, смертність, показники діяльності онкологічної служби) / Бюлетень наці-
Серед пацієнтів, яких прооперували у період 3 1990 до 1999 р. (контрольна група), ННК спостерігали у 176 (13,6 £ 0,9\%) пацієнтів. Серед пацієнтів, яких прооперували у період з 2000 до 2014 р. (досліджувана група), ННК спостерігається у 95 $(3,7 \pm 0,4) \%$ пацієнтів. Використання 3-етапної профілактики ННК із застосуванням розробленого комплексу профілактичних заходів дозволило зменшити ( $<<0,001$ за критерієм хі-квадрат) ризик развитку ННК у 3,7 раза, ОР=0,27 (95\% ДІ=0,22 $-0,35)$.

Висновки. 1. Оптимізована тактика лікування некрозу низведеної кишки залежно від часу iї виникнення і рівня некрозу: у пацієнтів з раннім високим некрозом низведеної кишки показана ампутація низведеної кишки, у пацієнтів з раннім низьким некрозом низведеної кишки показане донизведення низведеної кишки зі сторони промежини; у пацієнтів з пізнім некрозом низведеної кишки показане відключення лівої половини товстої кишки шляхом формування петельної трансверзостоми на правій половині товстої кишки 3 одночасним тампонуванням тазової порожнини i армуванням анального каналу для запобігання його стенозу.

2. Застосування розробленої тактики дозволило знизити $(\mathrm{p}<0,05)$ ризик післяопераційних ускладнень у цій категорії пацієнтів, ОР=0,54 (95 \% ДІ 0,29-0,99) порівняно з раніше використовуваною методикою (протягом періоду з 1990 до 1999 р.), післяопераційна летальність при цьому склала $(6,2 \pm 2,5)$ \%. Завдяки використанню розробленої тактики лікування спостерігається зменшення післяопераційної летальності у 2 рази - 3

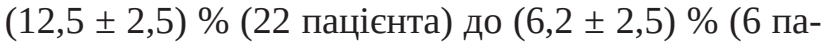
цієнтів) ( $=0,046)$.

Розроблена тактика лікування може бути застосована для лікування хворих на рак прямої кишки в хірургічних та онкохірургічних відділеннях України і дозволить в перспективі покращити безпосередні результати лікування цієї категорії пацієнтів за рахунок зменшення летальності. онального канцер-реєстру України. - К., 2008. - № 9. - 114 с. 4. http://www.moz.gov.ua/ua/portal/dn_20110429_247.html.

5. NCCN Guidelines Version 2.2017. Rectal Cancer.

6. Основы компьютерной биостатистики. Анализ информации в биологии, медицине и фармации статистическим пакетом MedStat / Лях Ю. Е., Гурьянов В. Г. Хоменко, В. Н., Панченко О. А. - Донецк : Папакица Е.К., 2006. - 214 с. 


\section{REFERENCES}

1. Rak v Ukraini v 2015-2016 r. (zakhvoriuvanist, smertnist, pokaznyky diialnosti onkolohichnoi sluzhby) [Cancer in Ukraine in 2015-2016 (morbidity, mortality, indicators of the oncology service activity)]. (2017). Biuleten natsionalnoho kantser-reiestru Ukrainy. - Bulletin of the National Chancery Register of Ukraine, 18, Kyiv [in Ukrainian].

2. Site Cancer Research UK. Bowel cancer incidence statistics. Retrieved from http://www.cancerresearchuk.org/health-professional/ cancer-statistics/statistics-by-cancer-type/bowel-cancer/incidence.

3. Rak v Ukraini v 2006-2007 r. (zakhvoriuvanist, smertnist, pokaznyky diialnosti onkolohichnoi sluzhby) [Cancer in Ukraine in 2006-2007 (morbidity, mortality, indicators of the oncology service activity)]. (2008). Biuleten natsionalnoho kantser-reiestru Ukrainy. - Bulletin of the National Chancery Register of Ukraine, 9. Kyiv [in Ukrainian].

4. Sait ministerstva okhorony zdorovia Ukrainy http://www. moz.gov.ua/ua/portal/dn_20110429_247.html [Ministry of Health of Ukraine ]. [in Ukrainian].

5. NCCN Guidelines Version 2.2017. Rectal Cancer.

6. Lyakh, Yu.E., Gurianov, V.G., Khomenko, V.N., \& Panchenko O.A. (2006). Osnovy kompyuternoy biostatistiki. Analiz informatsii v biologii. meditsine i farmatsii statisticheskim paketom [Cancer in Ukraine in 2006-2007 (morbidity, mortality, indicators of the oncology service activity)] Donetsk: Papakitsa E.K. [in Russian].

Отримано 23.01.2018

\author{
YU. V. DUMANSKY, S. P. VOLOSHIN
}

City Interdistrict Cancer Dispensary, Mariupol

\title{
IMMEDIATE RESULTS OF TREATMENT OF NECROSIS OF COLON TRANSPLANTAT AFTER SPHINCTER-SPARING SURGERY IN PATIENTS WITH RECTAL CANCER
}

\begin{abstract}
The aim of the work: to increase the effectiveness of treatment of patients with rectal cancer.
Materials and Methods. The material for the work was data on 271 patients with necrosis of the colon transplantat. All patients with this complication were divided into two groups: control (176 patients) and study (95 patients).

Results and Discussion. For the treatment of patients in the control group, colostomy was used; for the treatment of patients in the study group it was optimized the treatment approach depending on the time of its onset and the level of necrosis: in patients with early high necrosis of the colon transplantat, amputation of the colon transplantat should be performed, in patients with early low necrosis of the colon transplantat should be performed re-pull through operation from the side of the perineum; in patients with late necrosis of the colon transplantat, disconnection of the left half of the colon shold be performed by forming a loop transversome on the right side of the colon with simultaneous tamping of the pelvic cavity and amputation of the canal to prevent its stenosis.

Intraoperative complications were indicated in $(10.3 \pm 1.8) \%$, in the control group - in $(13.1 \pm 2.5) \%$. The use of the new approach let to reduce $(\mathrm{p}<0.05$ ) the risk of postoperative complications in this category of patients, $\mathrm{RR}=0.54$ (95\% CI 0.29-0.99) compared to the previously used technique. The incidence of postoperative complications was (21.6 \pm 3.1$) \%$ in the control group and (11.6 \pm 3.3$) \%$ in the study group. Thanks to the use of the developed treatment tactics, the decrease in postoperative mortality was reduced in 2 times - from (12.5 \pm 2.5$) \%$ (22 patients) to (6.2 \pm 2.5$) \%(6$ patients).
\end{abstract}

Key words: necrosis of the colon transplantat; colostomy; sphincter-saving operations; postoperative mortality.

\author{
Ю. В. ДУМАНСКИЙ, с. П. ВОлОшИН
}

Городской межрайонный онкологический диспансер, г. Мариуполь

\section{НЕПОСРЕДСТВЕННЫЕ РЕЗУЛЬТАТЫ .ЛЕЧЕНИЯ НЕКРОЗА НИЗВЕДЕННОЙ КИШКИ ПОС.ЛЕ СФИНКТЕРОСОХРАНЯЮЩИХ ОПЕРАЦИЙ У БОЛЬНЫХ РАКОМ ПРЯМОЙ КИШКИ}

Цель работы: повышение эффективности лечения больных раком прямой кишки.

Материалы и методы. Материалом для работы послужили данные о 271 пациенте с некрозом низведенной кишки. Всех больных с данным осложнением разделили на две группы: контрольную (176 пациентов) и исследуемую (95 пациентов).

Результаты исследований и их обсуждение. Для лечения больных контрольной группы применяли колостомию, для лечения пациентов исследуемой группы - оптимизирована тактика лечения некроза низведенной кишки в зависимости от времени его возникновения и уровня некроза: у пациентов с ранним высоким некрозом низведенной кишки показана ампутация низведенной кишки, у пациентов с ранним низким некрозом низведенной кишки показано донизведение низведенной кишки со стороны промежности; у пациентов с поздним некрозом низведенной кишки показано отключение левой половины толстой кишки путем формирования петлевой трансверзостомы на правой половине толстой кишки с одновременным тампонированием тазовой полости и армированием канала для предотвращения его стеноза.

Интраоперационные осложнения обозначались у $(10,3 \pm 1,8) \%$, в контрольной группе - у $(13,1 \pm 2,5)$ \%. Применение разработанной тактики позволило снизить (р<0,05) риск послеоперационных осложнений в этой категории пациентов, ОР=0,54 (95 \% ДИ 0,29$0,99)$ по сравнению с ранее использованной методикой. Частота послеоперационных осложнений составила $(21,6 \pm 3,1)$ \% в контрольной группе и $(11,6 \pm 3,3)$ \% в исследуемой группе. Благодаря использованию разработанной тактики лечения отмечается уменьшение послеоперационной летальности в 2 раза - с (12,5 $\pm 2,5)$ \% (22 пациента) до (6,2 $\pm 2,5)$ \% (6 пациентов).

Ключевые слова: некроз низведенной кишки; колостомия; сфинктеросохраняющие операции; послеоперационная летальность. 